WIENER SLAVISTISCHES JAHRBUCH, Band 55/2009, 85-96

(C) 2009 by Österreichische Akademie der Wissenschaften, Wien

ИННА ПЕЛЕВА

\title{
Бай Ганьо - проблематичният българин и шансовете на непреводимостта
}

Книгата с невероятните разкази за един съвременен българин, която Алеко Константинов издава през 1895 година, отдавна е придобила статуса на ключово за националната литературна класика произведение. Спрямо него се е осъществила практически необгледна поради смазващия си обем критическа рецепция: за „Бай Ганю“ през десетилетията пишат - и то „напрегнато“, с високи концептуални амбиции, нерядко с желание за спор - едва ли не всички български хуманитари авторитети (да споменем поне Александьр Теодоров-Балан, Пенчо Славейков, д-р Кръстев, Стоян Михайловски, Боян Пенев, Божан Ангелов, Владимир Василев, Малчо Николов, Владимир Полянов, Петьр Пондев, Иван Мешеков, Пантелей Зарев, Светлозар Игов, Михаил Неделчев, Никола Георгиев), както и стотици днес забравени (но не и безинтересни за историка на културата) интерпретатори.

Високата температура на нестихващия дебат около книгата е последица и от факта, че тя всъщност осъществява дискредитиращи, пародийни прочити на целия речник от емблеми и символизации на своето, с който борави официалната словесност на държавата България. Произведението разбива тухла по тухла скрепения от думи и разкази класически национален образ на света, деавтоматизира чрез снизяващ превод високите клишета на патриотическото, оспорва „обществения договор“ за използването на речта като инструмент за добро (защитно), себехаресващо се автопортретуване на колектива. Точно заради това текстьт „Бай Ганю“ може да се гледа като един от най-деструктивните жестове спрямо градежите и функциите на националната култура, преживени от нея.

Разбира се, вид защитна реакция срещу посегателствата, осъществени от творбата, е и дълголетният отказ на академичното критическо говорене да дефинира природата й в подобни на горните категорични формулировки. Но въпреки разнообразните стратегии за укриване, подменяне или ретуширане на агресиите спрямо българското, упражнявани от „Бай Ганю“, заплахите за на- 
ционалното самолюбие в произведението винаги са се обмисляли и преживявали - дори и когато е била на власт критическата аксиома „Бай Ганьо не $e$ българинът [...]“, т. е. когато старателно се е внушавало, че текстът не атакува просто и само „нас“, не описва просто и само „нас“ като нелепи, смешни, и отблъскващи, като неспособни на адаптация, жалки и постоянно наказвани, постоянно разлъчвани от добрата и красивата „Европа“.

Израз на перманентно тлеещото безпокойство, че (каквото и да твърдим, както и да я обясняваме) тази книга все пак „ни“ наранява, вреди „ни“ и „ни“ пречи, е един характерен детайл от историята на рецепцията й. Макар и под сурдинка, макар и под различни форми, в българска културна среда за немалък период от време отново и отново се възобновява тревожното, натоварено с лоши предчувствия питане: „Какво ще си кажат чужденците за нас, когато прочетат Алековото произведение?“

Според някои сънародници враждебността на „другите“ няма как да не намери речите си, словесните си мотивации точно през-чрез говор за Бай Ганьо. Например в началото на 1920-те Петко Росен с горчивина пише: „,...] naмemта ми съска злорадите думи на сърбите: ,Бугарашите убиха своя писател Алеко Константинов, защуото той със своя Бай Ганю ги представи пред света такива, каквито са' [...]“ (Росен 1922: 2). Пак по това време учител, гледал първия филм по Алековата творба, се възмущава: „[...] как е възможно да се допусне едно такова глупаво окарикатуряване на българския народ? Ами че този филм навярно ще прескочи границите на България и тогава в какво осветление ще ни видят европейците!“ (Люл 1922/23: 150). През 1930-те тревогата около реакциите на „другите“, които са видели портрет на нацията в „Бай Ганю“, е все така навременна за Йордан Бадев: „[...] книгата на Алеко бе преведена за десетина години на няколко европейски езици. И може би образът на Бай Ганю е играл някаква роля в отношението на чужди лица и среди към нас. Кой знае дали неприятели на народа ни не са взимали от характеристиката на Алека доводи за да ни хулят [...]“ (Бадев 1937: 12).

Гласът на същото това българско притеснение, опитващо се да позакрие мотивите си (те се коренят в убеждението, че Ганьо наистина е ужасен и заедно с това може да бъде мислен като въплъщение на българското), е „хванат“ още в предговора на професор Вайганд към превода на част от Алековата книга, направен от известния учен през 1908 г.: „Един българин ме попита защо съм избрал не друго, а именно ,Бай Ганьо', за да запознавам немџите с него, когато българите имали в своята литература много по-хубави и по-иенни работи“ (Герчев 1908/9: 77).

Отговорьт на Вайганд е категоричен и лесен: „Допущуам, при все това обаче, че в иялата българска литература няма второ произведение, което да е имало такъв несравнен успех и такова възпитателно значение върху българиmе, както ,Бай Ганьо““” Вайганд превежда точно Алековото съчинение и защото е сигурен: „в това произведение разговорният език се излага в чисто на- 
родни форми, когато в повечето други литературни произведения езикът е повече или по-малко изкуствен и в него ясно личи руското или немското влияние.“ В края на краищата професорът преврьща книгата (по-точно преведените разкази от първата й част: „Бай Ганю пътува“, „Бай Ганю в операта“, „Бай Ганю в банята“, „Бай Ганю в Дрезден“, „Бай Ганю на изложението в Прага“, „Бай Ганю у Иречек“ и „Бай Ганю на гости“) в учебно помагало по български език: „,... [то] допълва, така да се рече, излязлата от същия автор практическа българска граматика (Лайпичиг, 1907). Практическите упражнения по български език, които води уважаемият проф. Вайганд всеки летен семестьр при Лайпцигския университет, се извъриват именно по ,Бай Ганю “" (Ихчиев 1912: 479).

Но на немски - както забелязва български тогавашен коментатор - Бай Ганьо приказва всъщност по доста по-различен начин, отколкото в Алековата книга. „Силом хубост не бива“ за Вайганд е същото като „не мога да ви принуждавам“, „гел кефим гел“ през посредничеството на професора се завръща в българския като „сега той се чувства в стихията си“; „хич олмаса тоя дангалак е изял някоя [...] някоя попара““ пък - като „сигурно този негодник е направил някоя глупост“; Ганьовото „лъскава“ според немския учен е същото като „красива“, „апетитна“; „резил станахме“ от оригинала се превръща (след Вайганд) в „бяхме бламирани“, „палиха, смъдиха“ - в „и правиха Бог знай що още“, „има си хас“ - в „прелестно“ или „възможно ли е“, „емишерии“ - в „другари“ (Genossen), „нейсе, запуши я“ - в „да не говорим по-добре“, „,агарянски ямурлук“ - в ,aus der Türkenzeit stammenden Mantel aus Ziegenhaaren“, „,антерийка“ - в „Leibrock“ и т. н. (Герчев 1908/9: 77). Според Хр. Герчев Вайганд не е имало как да се справи адекватно и със „санким“, ,тюх да се не видеше макар“, „маскари“, „хаир сюйле“, „янлъш“, „хелбетя“, „чат-пат“, „язък“, „нафиле“, ,зор-заман“, „майка му стара“, „текмета“, „изръшнал“, „да му светнеш (една окица)“, „хепийдже“, „отпънал“, „бош лаф“, „фукара“, „сус бе, ченгене“ и пр. За Ихчиев пък твърде съмнително допустимо отклонение от оригинала е и това, дето ученият е решил да преведе невъзпитаното Ганьово „ти“ във възпитано второ лице множествено число: „ами какво стоиш в кафенето, като не си свободен“ - ако се завърне в българския от немския превод - вече би звучало като „но как можете да седите в кафене, щом не сте свободни“ и пр. Всъщност наймалкият проблем на Вайгандовия „Бай Ганю“ е това, дето според обяснителния апарат „Не щеме ний богатство“ е текст на Каравелов - забележките тук са излишни и защото сочещият грешката Ихчиев също греши, сочейки за автор на въпросното произведение Чинтулов (Ихчиев 1912: 481).

Любопитното е, че още повествователят в „Бай Ганю“ по някакъв начин, в някакъв смисъл предсказва част от Вайгандовите проблеми с езиковия трансфер на произведението от български на немски. Предсказал е не само тях, а изобщо разните трудности, разните типове невъзможности и несправяния, които биха сполетели всеки преводач, захванал се с невероятните разкази. Предсказал е провалите на всяка хипотетично възможна чуждоезикова версия на 
книгата, доколкото много настойчиво обсъжда лингвистичната страна - там е работата, че тя никога не е просто и само лингвистична - на неразбирането между „нас“ (българите) и „тях“ (европейците, другите); доколкото е забелязал и коментирал лоши асиметрии между набора понятийни полета, с който разполага „нашият“ речник, и репертоара на „техния“. Наличности в „тукашната“ езикова реалност са липси в „тамошната“, както и обратно, твърди нашият автор, и това също - освен всичко останало - прави проблематична превратимостта на едната в другата.

Българският език на героя от Алековата книга не знае например да казва всички онези меки, нежни, сърдечни обръщения, които характеризират отноченията на циивилизованите хора и които правят живота по-благ, по-приятен (повествователят все пак си дава труд да намекне, че родната му реч поне донякъде може да изиграе мекота, нежност и сърдечност, произнасяйки ... моля ви се, имайте добрината, бъдете тъй любезен ...). А другите не само използват меките, нежни и сърдечни обръщения. Те дори са създали понятия, означаващи онова, от което - като цялостен стил на държание - са „извадка“ добрите думи. Както и може да се очаква, нараторьт вижда злепоставящо признание в това, дето родната говорна практика не разполага със свои имена за речевото (и не само речево) поведение, което търси удоволствие от общуването във вниманието и почтителността към другия: „думите ,вежливост ', ,учтивост ' са новооткраднати от руски език, ,деликатност' е заета на заем от французите, а у нас най-подходящ за тия понятия термин е думата ,лигаване“" (Константинов 1987: 64). Краткият пасаж всъщност абсурдизира идеята за преводимост между световете - нима може да се постигне съотносимост на смислите, нима би останало нещо от превеждания френски текст, ако в българския на мястото на „деликатност“ се изпише „лигаване“ - думата, която според повествователя тук нарича означеното в чуждия речник от тамошната лексема. (Същият тип невъзможност за сговор между културите илюстрира и друг „преводачески“ казус, хванат в кадър от разказването: „Знам ги аз тях. Ти не ги гледай, че са такива м аз н и (Бай Ганьо искаше да каже у ч $т$ и в и, но тая дума е още нова в нашия лексикон, забравя се), не гледай, че се увиват около тебе. Защу се увиват? Мигар доброто ти мислят? Айни, звай, гут моргин, па все гледат да докопат нещзо [...] Просеции!“ (Константинов 1987: 2122). Българският, представян от книгата, не би могъл да бъде с някой от цивилизованите езици - като равнопоставен, „нормален“ партньор - в характерните отношения, предполагани от трансфера, наречен превод. Светът „ни“ не е дорасъл до способността да поеме, да издържи превеждането; много съдържания, формулирани в думи там, няма в какво да се огледат, да се излеят тук. Оскъдиците на своето тепърва ще трябва да се заличават чрез импорт на непреводими (всъщност) за „нас““ чужди понятия - те би трябвало да родят онова, което тукашното мислене, тукашното битие (както се вижда от зевовете в речника) не са успели да отгледат. 
Според разказващия в „Бай Ганю“ на фона на „европейските езици“ българският не само е белязан с лоши липси - пак спрямо тях той носи вини и защото съдържа лоши наличности: „[...] нещо к ь о р а в о , някой келепир [...] Дали има в европейските езици думи, съответствующи на тия, в това им значение“ (Константинов 1987: 55-56). Питането е реторическо; за нагласата, демонстрирана от повествователя в текста, е повече от сигурно, че понятия тамошни двойници на „кьораво“ и „келепир“ не съществуват - защото няма какво да назовават, защото „европейската“ душевност, „европейският“ начин на живот не познават идеята за сполука и печалба, утаена в словата, за пореден път разобличаващи българското. (Това, дето са български, ако и в буквалността на произхода си да са турски, прибавя още обвинения към родната, своята за автора на „Бай Ганю“ култура.)

Неговата книга вярва, че дори и когато преводимостта между „тук“ и „там“ е формално възможна, тя е само привидност. Пишещият илюстрира това си убеждение, като разиграва „хитър“ из речниковите територии на родното и на чуждото: „когато в другите народи думата, хитър“ е синоним с лукав, в е р о л о м е н и прикачена на някое лице, би го понижила в мнението на обществото, у нас с епитета х и $\mathrm{m}$ в $p$ се кичат като с най-почтена декорация: ,Бреей! хитро момче излезе, да е живо на бащча си, всинцุа ни измами! Не можахме да го излъжем. Аиколсун! Браво! “ (Константинов 1987: 55). Думата, заинтригувала прозаика, този път е заявена като налична и в двете (,тяхната““ и „нашата“) речникови системи. Само че, твърди пишещият, едно и същото всъщност нарича антонимни съдържания в „този“ и в „онзи“ свят. Реципрочната преводимост (за да минеш от режима на единия език в режима на другия, трябва да „преобърнеш“ оценъчността на думата, „тамошното“ черно е бяло „тук“, упрекът при „тях“ е похвала при „нас“) за пореден път - в артикулациите на невероятните разкази - доказва (освен минусовата качественост на „своето“) несъстоятелността на надеждите за сполучливо, истинно свеждане на „местна“ в „,европейска“ реч и обратно.

Възможността за удовлетворителна превратимост на едната в другата е особено остро отречена чрез играта с фразеологизмите в „Бай Ганю“: ,[...] cъчиняваше в ума си една фраза по немски, която да отговаря на нашето: ,де е онова, за голяма работа?' и най-сетне от буквалния превод скомбинира фразата: ,Wo ist diese für gross Arbeit? ““ (Константинов 1987: 59).

Нелепото калкиране се повтаря и завтаря в „Бай Ганю на гости“, докато най-после се чуе това, което пишещият иска да чуем. Чрез инсценирането на страничната гледна точка, на слуха на чужденеца, повествованието остранява българския въздебелашки евфемизъм, посочва грозно-глупавото в него, онова, което казва като че ли нелицеприятни неща за манталитета, произвел езиковото изделие. Бай Ганьо съобщава (в края на краищата), че търси клозет, а чешките му домакини го разбират съвсем другояче: „[...] жените помислиха, че той им съобщава, че е дошъл да върши големи работи, голяма търговия с ро- 
зово масло“ (Константинов 1987: 60). За един езиково-мисловен контекст, за една нация „голяма работа“ е най-вероятно да означава амбициозни начинания, сделки, печалби и пр., за друг „етнически“ тип обвързване между думи и неща „голяма работа“ нарича дефекацията - най-низменото на укриваната, некрасивата физиология. Дори и отвъд нередния от гледна точка на преводаческото изкуство Ганьов буквален превод на фразеология нима би могъл да съществува (всъщност) някакъв правилен „превод“, способен наистина да обясни на „онзи“ свят света, където ходенето по нужда се титулува и величае като „голямата работа“. Коментирайки липси и наличности, специфични петрифицирани словосъчетания, така или иначе правещи тъканта на груповото съзнание, пишещият в „Бай Ганю“ отново и отново рисува българското като положено в несподелимостта, като обречено на непреводимост.

Из страниците с невероятните разкази проблемите около превода са буквализирани и в сравнително често повтаряща се ситуация - Ганьо търси кой да го „сговаря“ с чужденците и покрай това някой се оказва въвлечен в ролята на негов преводач. Несводимостта на „техния“ към „нашия“ свят и обратно става твърде осезаема, когато дори отзовалият се наличен посредник билингвист (в широкия културологичен обхват на понятието) се проваля като адекватно преврьщащ смисли и значения от единия в другия семантически режим.

Между другото в текста чужденецът, който знае български (и всичко, стоящо зад този език), е един-единствен, толкова единствен, че влиза в разказването с лично име - става дума за Иречек. Бидейки на гости у знаменития чех, Бай Ганьо се одумва домакинът да му превежда при предстоящата търговия; но естествено свенливо-нахалното предложение остава без последици. Ако има осъществен опит за превод в сюжета, посредникът се оказва все откъм „нас“ - той винаги е сънародник, научил речите на чуждото.

По волята на повествуващия ролята на медиатор между „своя“, превърнал се в бреме от срам, и другия, мечтания свят, оказва се, изправя пред мъчителен избор - между истината, която товари посредника с непоправими щети, и неистината, която спасява превеждащия (Ганьо на другите) от трагическата (по същество) вина на българскостта. Човекът между културните битиета е в драма, в невъзможност да изпълни предполаганата като обърната към доброто и полезното задача (комуникацията, разбирането били „добро“ и „полезно“). Той не може да „преведе“ Бай Ганьо на образцовите чужденци, защото ще изгуби собствения си приличен изглед, всяко съобщаване на същинското българско зачертава шансовете на всеки българин. Неможещ да понася тягостния си сънародник, за да се защити, „посредникът“ защитава Бай Ганьо, за да защити Бай Ганьо, льже, льже ли, в края на краищата доказва живия Ганьо в себе си. Гонейки облага, отвратителният Бодков твърди пред чешките си хазаи, че новопоявилият се в дома им българин е не просто негов роднина, ами и милионер, който „има сума фабрики за розово масло“ (Константинов 1987: 57). Не е генерално различен ходът, избран от студента идеологически двойник на авто- 
ра, когато за пореден път се налага търговецът да бъде представян на чужденци: ,,- Този ли господин е братът на mademoiselle Marie? - попита ме един от домашните. Аз му отговорих утвърдително, като прибавих за оправдание на Бай Ганювото поведение и външност една набързо скроена лъжа; казах му, че телеграмата със скръбното известие намерила Бай Ганя в неговия чифлик, когато той надзиравал полските си работи, и че без да се отбива във вилата си (Бай Ганю и вила!), той отишел на железнищата, снабдил се с пари от познатите на гарата и дошъл в Дрезден, без да се спира някъде. А сегашното му поведение, ако и да изглежда странно, трябва да му се прости, като се има предвид поражающето впечатление, което му произвожда незаменимата загуба на сестра му и [...] огромните загуби, които претърпява от несвоевременното напущане на полските си работи“ (Константинов 1987: 32).

Принадлежността, излиза, е доживотен затвор без право на помилване, тя не позволява нечие измъкване, нечие оразличаване - Бай Ганьо придърпва „в себе си“ оказалия се наоколо, заразява с ганьовското си и онзи (или само проявява наличното в него), по рождение белязан с българскост, който би искал да я отмести от себе си. Разказите избликват под натиска на желанието да се изпише надпоставеността на Студента билингвист спрямо Търговеца, владеещ един-единствен език, да се дегустира удовлетворяващото различие между тях. На места обаче насладният властови проект се проваля и разказването - като че ли против предварителни намерения - преобръща йерархиите между силен и слаб, владеещ и владян. Студентът, знаещ езиците, метаморфозира в слуга на подтичващия, молещия с притреперващ глас безпомощен в чужбина простак (Ковачев 1999: 38-42). Образованият, уж успял да се освободи от етнопринадлежността си, се оказва хванат в капана на обстоятелствата - в капана на нежеланието да има тази родина, която има. Точно това го превръща в нещо като Котарака в чизми, който лъже заради господаря си, осигурявайки му достъп до среда, която не му се полага - затъването в мразеното свое, в измамите му, е неминуемо. С други думи комуникацията между „нашия“ и съвършения свят е невъзможна и защото този, който - по презумпция - би трябвало да я удържа, да я подсигурява чрез превода, избира вместо преводач да бъде автор. Заради икономиката на щети и ползи посредникът организира подмяна, не възпроизвежда „дадения“ текст, а съчинява нов, друг. Всъщност тази ситуация се е разигравала и в други места от книгата: при трьгването за Прага първоначалната идея е „да ни видят европейците“, но в края на краищата писането „естествено“ стига до поуката-внушение, че единственият шанс на „своето“ е да остане скрито и невидяно; всяко научаване на истината за него, всяко съзиране на лицето му без макиаж биха довели до абсолютния му провал. Подобна парабола се чертае отново и отново в текста. Разказите неведнъж корят своето заради неговата затвореност, заради некомуникабилността му. Но пък, както излиза от „Бай Ганю в Дрезден“, точно ликвидирането на възможността за пълноценна комуникация - онази, която се базира на пренос на истинни значения, може 
да осигури (поне отчасти и донякъде) допускането, изтърпяването „ни“ в залите на образцовата култура. Вместо да разкаже за своето в неговата собствена правда (то е точно това и такова, което-каквото възмущава западните люде), посредникът използва омонимическите спрямо чуждото негови места, за да твърди, че нашето все пак е същото като тяхното, макар и тяхното не от централните, здравите, престижните пространства (,умопомрачен от скръб“). Автентиката не е ценност, тя е само ужасна тегоба, която трябва да се престорва, укрива, преправя. Комуникация като себе си е невъзможна или най-малкото нежелана, защото автоматически би довела до прогонване от общото пространство. Пред българското, каквото е за книгата, стои странен избор - или прекъсване на канала за свръзка поради изпъждането „ни“ след признание за това кои „сме“ и какви „сме“, или удържане на „наше“ присъствие в диалогичното, но чрез лъжата, т. е. чрез презумптивното приемане, че контактът като казване на истина, като разкриване на себе си е немислим, че пълноценният, адекватният, точният, истинният превод е нещо, което не можем нито да си позволим, нито да желаем, защото само би ни навредило. Изолация поради наше нежелание да си приказваме с „тяхното“ (чунким бащз ми...), изолация поради това, че „сме“ наказателно въдворявани навън (примерно от разпоредителя в операта), прогонвани с шамари, изолация на истинските „нас“, налагана от амбициозния говор на европеизирания сънародник (вече измамник), опитващ се да „ни“ удържи в невидимост, приписващ „ни“ нямани богатства и чувства и заедно с това - „европейскостта“ на тамошното болно, лудо, абнормално („Бай Ганю в Дрезден“) - изолацията е единствената съдба на своето ...

Наказанията й изглеждат неотвратимо предстоящи „ни“, особено когато се появява преводач на „Бай Ганю“ като Вайганд - той не е сънародник и не би „лъгал“ - в края на краищата - заради „нас“, макар че първоначалната му грижа би била евентуално да защити просто себе си, ретуширайки целенасочено едно или друго от образа на героя. Случва се обаче това, че Вайганд, представяйки „Бай Ганю“ (което автоматичечски означава и Бай Ганьо) на немски, всъщност - без да го иска или съзнава - върши (от определена гледна точка) същото, което върши и българинът преводач във фикционалния свят на произведението: превеждайки, не разкрива, а скрива. Най-мрачните предчувствия на местния интелигент („какво ще кажат другите за „нас“, когато прочетат онази книга“) се оказват измамни. Излиза, че „през“ превод „те“ не могат да видят докрай колко „сме“ грозни, прости, груби, ужасни според свидетелския разказ на един „вътрешен“ човек, не могат да чуят истински просташката „ни“ звучност. Престижният европейски език, наел се да представи собствената „ни“ реч за „нашето“, нормализира българското, смекчава, някак „окултурява“ звучността и интонирането му: ако немският „Бай Ганю“ се превърне-завърне в пак тукашна реч, сред получените страници ще липсват много от онези словесни пейзажи, които мотивират негативното повествователско отношение спрямо прословутия герой. Каква ирония - ако ще „им“ се показва точно този текст, 
непреводимостта му, неговият неминуемо лош смислово-езиков „трансфер“ са шанс за удовлетворяващ (понеже е щадящ) груповото самолюбие контакт с другите. И гаранция, че никога няма да научат български - във всеки смисъл на фразата. Току-що реченото не е опит да се представи като уникален един универсален проблем - аксиома е, че всеки превод има своите недоуспявания; всеки национален литературен шедьовър, писан на съответния национален език (няма да размишляваме точно сега дали „Бай Ганю“ е точно шедьовър), може да бъде видян, да бъде „доказван“ като непреводим. Специфичното на обсъждания казус е, че в „българския случай“ за част от интелигентската публика на страната традиционната констатация за невъзможността на превода да „побере“ всичко онова, което е текстът като оригинална, първозданна езикова материя, не би била обвързана с традиционното тьгуване заради „загубите“ при трансфера. Поради твърде особената роля на „Бай Ганю“ в етническия културен живот въпросните неминуеми ,загуби“ при превода му най-неочаквано, в разрез с конвенционалното разбиране за максимално пълната, „безостатъчно“ осъществената комуникация като идеалната, желаната, истински потребната (макар и неосъществима в реалността) комуникация, могат да се окажат полезни, могат да се окажат добро в характерен социокултурен момент и според характерна аудитория ...

Френският превод на „Бай Ганю“ от 1911 г. с встъпителни думи от Луи Леже, освен че има подобни на немския проблеми с адекватното прерисуване на екзотичния персонаж - т. е. по подобен начин ретушира портрета му, смекчава чертите му, - прави и още нещо. Заглавието на книгата при първата й поява пред френска публика гласи „Бай Ганю. Българският Тартарен“ (Konstantinov 1911). За тукашния критически говор съпоставимостта между героите на Алфонс Доде и на Алеко Константинов е спорно защитима (Кръстев 1978: 211-214). Преводачите обаче така или иначе полагат фигурата на приликата между френско/тарасконско и българско в заглавието на предназначения за тамошния читател наш текст. Постулирането на такова подобие в самото наричане на историите, приготвени за „техните“ очи, е в противоречие с ясно четими авторови интенции, вместени в книгата - ганьовското българско, според тях, няма нищо общо с „френското“ (каквото и да е то - Алеко е чужд на мисълта, че има различни видове „френскост“). Освен това аналогията, изведена в заглавието, налага гледане към персонажа, което трудно би довидяло отвратата на наратора българин спрямо персонажа българин - защото я няма като повествователско отношение към французина герой в книгата на французина Доде. Т. е. преводът отново се случва като операция по омекотяване, по редактиране на посланията, излъчвани от произведението, по спасяването на „своето“ (не само за пред „тях“, а и за пред „нас“) от по-точното му - т. е. вярното на алековския негативизъм - четене.

Разбира се, така потребното „ни“ справяне с травмиращия натиск на текста, трупащ упреци спрямо българското, не разчита единствено на играта със спе- 
цифичната невидимост на част от Алековите внушения при преформатирането на оригинала в чужда езиковост. Откак особената книга излиза от печат, и във високите, и в ниските етажи на националната култура текат разнообразни в технологиите си процедури, обезопасяващи по един или друг начин „местната“ комуникация с произведението. За свършената работа по характерната му подмяна, по „ослепяването“ за автентичните авторови послания в творбата свидетелстват и промените в реакциите спрямо факта, че чужденецът също ще чете невероятните разкази, спрямо факта на тяхната преводимост/непреводимост.

От някъде нататък случилото се покрай първите преводи „за Запада“ двусмислено откритие, че текстът всъщност е неуловим за немския и за френския (а от това можем само да спечелим), се оказва някак ненужно, някак нарочно забравено. Дори през 1924 г. на списание „Подвиг“ му хрумва, че френски може да се научи точно чрез/по Ганьовите истории - идеята безспорно е заредена със специфична победност (Без автор 1924: 1-29). Тя, естествено, е в скандален разрез с всяка методическа коректност относно преподаването на нематерен език. Според правилата художественият текст (когато се стигне дотам), използван при обучението като илюстрация-въплъщение на несвоята реч, трябва да е не превод, а оригинал, принадлежащ на съответната чужда среда. Книжката от Библиотеката на списание „Подвиг“ използва не просто български текст, преведен на френски, за да ни помогне в ученето на ценния западен език. Въпросният български текст представлява ни повече, ни по-малко няколко страници от „Бай Ганю“. Именно в тази книга авторът всячески е оспорил „нашата“ способност да се справим с френския: „[...] българи студенти [...] почти ни един от тях не говореше сносно френския език. Не успее да зине на този език, и по грубостта на интонацията, по дикцията, по конструкцията на фразите ще го познаеш, че е възточен човек“ (Константинов 1987: 71); именно в тази книга героят казва „на френски“ единствено „Пърдон! и Гарсон бе, хей! юн каве [...]. Юн каве е апорт газет булгар“ (Константинов 1987: 74) - изписването на „тяхното“ с кирилските букви го лишава от автентичната му фонетика, прави чуваемо грубото му побългаряване (,бе“ и „хей“, вметнати в уж чуждоезиковата фраза, пак сочат как не можем да превъзмогне себе си, да мимикрираме, да звучим „като другите“). Та точно този текст, преведен на един френски, който изписва „кеф“, обяснява под линия „мускал“, „антерия“, „гемиджийската“, превежда и Ганьовия румънски, заменя „ахмак жена“ с „глупава жена“ и пр., се предлага като тренажор за усвояващите езика на Расин, Бодлер, Маларме. Жестът е поредна конкретизация на културната потребност, която - от 90-те на XIX в. до днес - настойчиво поправя, замества с нещо друго произведението, въвело в живота на групата онзи непреодолим сънародник.

Преводът превръща книгата в „друго“ и когато е по-скоро означение на политическа сюжетика, отколкото „филологическо дело“. През 1939-а, годината, дала началото на Втората световна война, вестниците верифицират политичес- 
ките „ни“ приятелства, неминуемо споменавайки и за превеждането на „Бай Ганю“ за съответната чужда публика - то се тълкува като доказателство за добри чувства спрямо „нас“ и трябва да провокира ответни добри чувства спрямо „тях“. „Голямата привързаност на словенския народ към делото на българо-югославското сближение и разбирателство“ например личи и в дейността на „Люблянската лига сред учещзата се младеж за изучаване на български език. Интересът и привързаността към българския език е довела вече до знанието му в такава степен [...], [че] един от тия ученици, името на когото не можах да запомня, е превел вече целия ,Бай Ганю“ на Алеко Константинов" (Без автор 1939а: 3).

Къде ще „сме“ през Втората световна личи и в начина, по който информацията за поредния превод на „Бай Ганю“ е поместена в една вестникарска страница от началото на 1939 г.: ,[...] Известният у нас италиански професор Енрике Дамяни, който познава много добре българския език и българската литература е превел недавна големия роман на Ив. Вазов ,Под игото “ и ,Бай Ганю' от А. Константинов [...]. Проф. Дамяни работи сега усилено върху новия си научен труд ,История на българската литература' [...]. Делото на г. Дамяни заслужава похвала, като се има пред вид, че той работи за опознаването на българската култура в Италия съвсем безвъзмездно“ (Без автор 1939б: 8). Информацията е монтирана сред материал за френска публицистка, издала книга за България, в която книга има ,много приятелски чувства [...] много точни преценки върху справедливата българска кауза“ снимки на двама хърватски учени - големи приятели на България, и най-вече - възхитен текст за „модерно село за работниции в Италия“ което са казва Мусолини и пред чийто паметник на работническия труд отдава почест водачът на италианския народ Мусолини. В съобщенията за нов превод на Алековата книга от това време вече няма и следа от тревога какво ще си кажат чужденците за „нас“, а спокойно приемане на добронамерения им жест към една национална емблема - новата война също както предишните изчиства от образа на героя притеснителното за сънародника, мобилизира-консолидира масовото разбиране (остро конфронтиращо се с авторовото) за него като за въплъщение на позитивно-борбеното. Понятийният ред „Бай Ганю“ - „справедливата българска кауза“ - „приятелски чувства“ (между държави с профашистка ориентация) - „Мусолини“ всъщност не е хаотично и алогично, „безсинтаксисно“ струпване на имена. Както не е алогично и това, че най-радикалният опит да се изтьлкува Алековата книга отвъд и срещу вписаните в нея интенции се появява именно в рамките на Втората световна война ... (Ралчев 1943).

И така, историята на превеждането на невероятните разкази и на реакциите спрямо чуждоезиковите им версии е своеобразна илюстрация на това как през времето българската култура се съгласява или не се съгласява с Алековите визии за „нашето“. Невъзможен за превеждане или напротив, преводим (за зло или за добро) - точно тези консумирани „у дома“ образи на текста „Бай Ганю“, 
вписващи в себе си и обмислянето на евентуалните чужди мнения за него, казват много за колебанията на една култура между порива по херметизация и желанието за отваряне, между себенехаресването и помиряването с дадената „по рождение“ етнопринадлежност, между боязънта от другите и потребността от близост с тях.

Литература

Бадев 1937:

Без автор 1924:

Без автор 1939а:

Без автор 1939б:

Герчев 1908/9:

Ихчиев 1912:

Ковачев 1999: О. Ковачев, Книга за слугата-господар или в търсене на изгубена-

Й. Бадев, „Бай Ганю“ за байганювщината (По случай 40 години от смъртта на Алеко Константинов), в: Зора 5371, София, 12

Без автор, „Бай Ганю“ на френски и на български. Избрани страници за изучаване на чужди езици чрез превод, в: Библиотека на сп. „Подвиг“, София, 1-29

Без автор, Огромният успех на изложбата на българската книга в Любляна, в: Вечер 6, София, 3

Без автор, Новите трудове на проф. Е. Дамяни, в: Днес 886, София, 8

Хр. Герчев, „Бай Ганьо“ на немски, в: Учителски вестник 5, 77

Н. Ихчиев, Aleko Konstantinovs Baj Ganju, herausgegeben, übersetzt und erläutert von Prof. D-r G. Weigand, в: Българска сбирка 6-7, юни-юли, 479-481 та идентичност, в: Д. Михайлов (съст.), Българска литература. Критически текстове за Алеко Константинов, Елин Пелин, Йордан Йовков, Велико Търново, 38-42

Константинов 1987: А. Константинов, Бай Ганю, в: А. Константинов, Съчинения в два тома, София, т. 1, 1-90

Кръстев 1978:

Кр. Кръстев, Бай Ганьо и Тартарен [1907], в: Кр. Кръстев, Етюди, критики, рецензии, София, 211-214

Люл 1922/23: Д. Люл, Бай Ганю в кинематографа, в: Учителски вестник 19, София, 150

Ралчев 1943:

М. Ралчев, Истинският „Бай Ганю“, София

Росен 1922:

П. Росен, Бележка, в: Пряпорец 95, София, 2

Konstantinov 1911: A. Konstantinov, Baj Gagno. Le Tartarin Bulgare. Trad. du bulg. par Matei Guerguiev et Jean Jagershmidt. Avec une pref. de Louis Leger, Paris

A b stra c t: Bai Ganio: the Problematic Bulgarian and the Chances of Untranslatability. According to some Bulgarian commentators, the hostility of "foreigners" towards "us" will inevitably find strong support in Bai Ganio (1895, Aleko Konstantinov). Others, however, seem undisturbed by the news about a new translation of the famous work; instead, they are gratified to see this goodwill gesture on the part of "foreigners" towards a "national monument". The debate over Bai Ganio's (un)translatability generates views of the text that can reveal a lot about a culture's fluctuations between the poles of self-negation and reconciliation with one's ethnic belonging, between bashfulness about encountering "the others" and the need to approach them.

K e y w or d s : Bulgarian culture, intercultural communication, translation

Инна Пелева

Пловдивски университет „Паисий Хилендарски“

ул. „Цар Асен“, 24, 4000 Пловдив, Bulgarien

peleva@uni-plovdiv.bg 